\title{
Absorption and metabolism of glucose by the mesenteric-drained viscera of sheep fed on dried-grass or ground, maize-based diets
}

\author{
BY A. N. JANES*, T. E. C. WEEKES† AND D. G. ARMSTRONG \\ Department of Agricultural Biochemistry and Nutrition, University of Newcastle upon \\ Tyne, Newcastle upon Tyne, NE1 $7 R U$
}

(Received 10 December 1984 - Accepted 25 March 1985)

\begin{abstract}
1. Sheep fitted with re-entrant canulas in the proximal duodenum and terminal ileum were used to determine the amount of $\alpha$-glucoside entering, and apparently disappearing from, the small intestine when either dried-grass or ground maize-based diets were fed. The fate of any $\alpha$-glucoside entering the small intestine was studied by comparing the net disappearance of such $\alpha$-glucoside from the small intestine with the absorption of glucose into the mesenteric venous blood.

2. Glucose absorption from the small intestine was measured in sheep equipped with catheters in the mesenteric vein and carotid artery. A continuous infusion of $\left[6-{ }^{3} \mathrm{H}\right]$ glucose was used to determine glucose utilization by the mesenteric-drained viscera and the whole-body glucose turnover rate (GTR).

3. The amounts of $\alpha$-glucoside entering the small intestine when the dried-grass and maize-based diets were given were 13.9 (SE 1.5) and 95.4 (SE 16-2) g/24 h respectively; apparent digestibilities of such $\alpha$-glucoside in the small intestine were 60 and $90 \%$ respectively.

4. The net absorption of glucose into the mesenteric venous blood was $-2 \cdot 03$ (SE 1.20) and 19.28 (SE 0.75) $\mathrm{mmol} / \mathrm{h}$ for the dried-grass and maize-based diets respectively. Similarly, total glucose absorption amounted to 1.52 (SE 1.35) and 23.33 (SE 1.86 ) $\mathrm{mmol} / \mathrm{h}$ (equivalent to 7 and $101 \mathrm{~g} / 24 \mathrm{~h}$ respectively). These values represented 83 and $111 \%$ of the $\alpha$-glucoside apparently disappearing from the small intestine, determined using the re-entrant cannulated sheep.

5. Total glucose absorption represented 8 and $61 \%$ of the whole-body GTR for the dried-grass and maize-based diets respectively. Endogenous glucose production was significantly lower when the sheep were fed on the maizebased diet compared with the dried-grass diet.

6. The mesenteric-drained viscera metabolized a small amount of glucose, equivalent to 234 and $17 \%$ of the total glucose absorbed for the dried-grass and maize-based diets respectively.

7. It is concluded that a large proportion of the starch entering the small intestine of sheep given a maize-based diet is digested and absorbed as glucose, and thus contributes to the whole-body GTR.
\end{abstract}

As a result of the rumen fermentation of dietary glucose and starch-like polymers, little glucose is normally absorbed from the ruminant digestive tract (Armstrong \& Smithard, 1979). The animal, therefore, relies mainly on the process of gluconeogenesis to provide a supply of glucose. However, when non-heat-treated maize is fed to sheep, some dietary starch escapes rumen fermentation and is available for digestion in the small intestine (Tucker et al. 1966; Hogue et al. 1968; Tucker et al. 1968; Ørskov et al. 1969; Beever et al. 1970). Clearly, this starch, if digested and absorbed in the small intestine, could make a significant contribution to the whole-body glucose production rate.

It is not clear, however, what proportion of the starch entering the small intestine is actually absorbed as glucose. Some, or all, may undergo microbial fermentation in the small intestine. Furthermore, glucose absorbed from the small intestine may be metabolized in the intestinal epithelium. There is evidence that the capacity of the ruminant small intestine to digest starch may be limited (Karr et al. 1966; Mayes \& Ørskov, 1974; Russell et al. 1981), although the sheep may be capable of at least some degree of adaptation through changes in the activities of the small intestinal carbohydrase enzymes (Clary et al. 1967; Janes et al. 1985). Glucose absorption may be determined by multiplying the difference in glucose concentrations of the blood supplying and draining the small intestine by the appropriate

* Present address: Nitrovit Ltd, Enterprise Farm, Pilmoor, Helperby, York.

$\uparrow$ For reprints. 
rate of blood flow; for such studies samples of mesenteric venous rather than portal venous blood are preferable (Janes et al. 1984).

The objectives of the present study were, first, to compare the amount of starch apparently disappearing from the small intestinal lumen with the amount of glucose absorbed into the mesenteric venous blood in sheep fed on dried-grass or maize-based diets, second, to measure the contribution of glucose absorbed from the small intestine to the whole-body glucose production rate.

A preliminary report of part of the results from the animals used in the net absorption studies was included in a previous publication detailing the technique of catheterizing the mesenteric vein (Janes et al. 1984).

\section{METHODS \\ Animals and diets}

Five cross-bred wethers with a mean body-weight of 48.5 (SE $3 \cdot 1$ ) $\mathrm{kg}$ were used for the intestinal absorption studies. At least $14 \mathrm{~d}$ before commencing experiments, each animal had a catheter surgically implanted in the mesenteric vein (sampling catheter) so that the tip lay immediately before the branch point with the gastrosplenic vein, and other catheters implanted in the mesenteric vein (infusion) and carotid artery (sampling) as described previously (Janes et al. 1984). In addition, a polyvinylchloride catheter was inserted into a jugular vein at least $24 \mathrm{~h}$ before each experiment. The net disappearance of starch from the small intestine was determined using eight similar cross-bred wethers (mean body-weight $55.0(\mathrm{SE} 1.3) \mathrm{kg}$ ) fitted with re-entrant cannulas in the proximal duodenum and terminal ileum.

The diets used were either ground and pelleted dried grass $(889 \mathrm{~g}$ dry matter (DM) $/ \mathrm{kg}$, $171 \mathrm{~g}$ crude protein (nitrogen $\times 6.25) / \mathrm{kg} \mathrm{DM}$ ) or a pelleted maize-based concentrate containing $778 \mathrm{~g}$ ground maize, $97 \mathrm{~g}$ ground dried grass, $64 \mathrm{~g}$ fishmeal, $18 \mathrm{~g}$ mineral-vitamin mix and $43 \mathrm{~g}$ molasses $/ \mathrm{kg} \mathrm{DM}(878 \mathrm{~g} \mathrm{DM} / \mathrm{kg}, 148 \mathrm{~g}$ crude protein $/ \mathrm{kg} \mathrm{DM})$. Both diets were given at hourly intervals by means of continuous belt feeders at the rate of $1 \mathrm{~kg} / \mathrm{d}$ (as fed basis). When the maize-based diet was given, a supplement of $100 \mathrm{~g}$ chopped dried grass $(853 \mathrm{~g} \mathrm{DM} / \mathrm{kg}, 113 \mathrm{~g}$ crude protein $/ \mathrm{kg} \mathrm{DM}$ ) was given in two equal portions at 08.00 and 16.00 hours to prevent rumen dysfunction. When the diets were given to the re-entrant cannulated animals, chromic oxide $(2 \mathrm{~g} / \mathrm{d})$ was incorporated into the diets in order to act as an indigestible marker. For the net disappearance studies, four sheep were fed on the dried-grass diet and four different sheep were fed on the maize-based diet. The catheterized sheep received both the dried-grass and maize-based diets which were randomized to periods independently for each sheep with three of the five sheep receiving the dried grass before the maize-based diet. In all experiments, at least $10 \mathrm{~d}$ were allowed for dietary adaptation before sampling blood or digesta. Drinking water was available at all times and there were no feed refusals.

\section{Experimental procedure}

The following procedure was performed on the catheterized sheep in both experimental periods. A primed, continuous infusion of $\mathrm{D}-\left[6{ }^{3} \mathrm{H}\right] \mathrm{glucose}$ was commenced via the jugular vein catheter. The priming dose and infusion rate were approximately $30 \mu \mathrm{Ci}$ and $0.5 \mu \mathrm{Ci} / \mathrm{min}$ respectively. After $60 \mathrm{~min}$, an infusion of sodium $p$-aminohippurate $(0.72 \mathrm{~g} / \mathrm{h}$; $\mathrm{PAH})$ was commenced via the mesenteric infusion catheter in order to determine the rate of blood flow in the mesenteric vein (Katz \& Bergman, 1969). After a further $60 \mathrm{~min}$, blood samples $(10 \mathrm{ml})$ were taken simultaneously from the mesenteric vein and carotid artery at intervals of not less than 15 min until ten pairs of samples had been collected; the infusions 
were then discontinued. All samples were subsampled for immediate determination of haemoglobin concentration $(0.05 \mathrm{ml}$ whole blood) and for subsequent determination of PAH concentration $(1 \mathrm{ml}$ whole blood deproteinized with $12 \mathrm{ml}$ trichloroacetic acid $(100 \mathrm{~g} / 1))$, glucose concentration $(0.5 \mathrm{ml}$ whole blood added to a clean sample tube containing $1.4 \mathrm{mg}$ sodium fluoride), $\mathrm{L}$ - and D-lactate concentrations and glucose and lactate specific activities ( $3 \mathrm{ml}$ whole blood deproteinized with $3 \mathrm{ml} 3 \mathrm{M}$-perchloric acid).

The experiment involving the re-entrant cannulated animals consisted of a $7 \mathrm{~d}$ collection of faeces and $24 \mathrm{~h}$ collections of duodenal and ileal digesta, with at least $3 \mathrm{~d}$ being allowed between collections.

\section{Chemical methods}

Colorimetric methods of determining PAH (Katz \& Bergman, 1969) and haemoglobin (Eilers, 1967) concentrations in whole blood were used. Concentrations of glucose in whole blood were determined enzymically using a YSI 23A Glucose Analyzer (Clandon Scientific Ltd, Aldershot, Hants). The supernatant fraction derived from whole blood deproteinized with perchloric acid was neutralized with potassium hydroxide before analysing for L-lactate and D-lactate concentrations using L-lactic dehydrogenase $(E C 1.1 .1 .27)$ and D-lactic dehydrogenase (EC 1 1 1 1 .28) (Sigma Chemical Co, Poole, Dorset) respectively (Gawehn $\&$ Bergmeyer, 1974). Glucose and lactate were separated for determination of specific activities using a modification of the method of Katz et al. (1981). Neutralized supernatant fraction $(2 \mathrm{ml})$ was passed through two tandem ion-exchange-resin columns. The first column $(50 \times 10 \mathrm{~mm})$ contained Dowex $50\left(\mathrm{H}^{+}\right.$form, $100 \mathrm{mesh}$; Sigma Chemical Co. $)$ and the second column $(60 \times 10 \mathrm{~mm})$ Dowex 1 (acetate form, $200 \mathrm{mesh})$. Each sample was washed through the columns with $10 \mathrm{ml}$ distilled water, with the eluate from the second column (containing the glucose fraction) being collected in a scintillation vial. The columns were then separated and the first column, containing most of the amino acid fraction, was eluted with $5 \mathrm{ml} 2 \mathrm{M}$-ammonium hydroxide, collecting the eluate in a second scintillation vial. The second column, containing the lactate fraction, was eluted with $5 \mathrm{ml} 2 \mathrm{M}$-acetic acid again collecting the eluate in a scintillation vial. Each column was used only once before regeneration of the resin. Since only background radioactivity was observed in the amino acid fraction eluted from the first column, no further isolation of this fraction was attempted. The two remaining eluates were lyophilized and redissolved in $1 \mathrm{ml}$ distilled water. Portions were taken for the determination of glucose and lactate concentrations as appropriate and the remainder mixed with $10 \mathrm{ml}$ scintillation fluid (Ready-Solv; Beckman RIIC Ltd, High Wycombe, Bucks) for counting in a Beckman LS 8100 Liquid Scintillation Counter. Counting efficiency was determined by the $\mathrm{H}$-number method of quench monitoring, which relies on the inflection point of the Compton edge generated using an external ${ }^{137} \mathrm{Cs}$ source.

$\mathrm{Cr}_{2} \mathrm{O}_{3}$ in feed, digesta and faeces was determined by the method of Williams et al. (1962). Samples of feed, duodenal and ileal digesta and faeces were analysed for $\alpha$-linked glucose polymer by a modified version of the method of MacRae \& Armstrong (1966). Results are presented as amounts of $\alpha$-glucoside, which relate to the amount of glucose produced on hydrolysis of the polymer; for conversion to starch, results should be divided by $1 \cdot 111$.

\section{Calculations and statistical methods}

Net disappearance studies. $\mathrm{Cr}_{2} \mathrm{O}_{3}$ recoveries were used to correct observed $24 \mathrm{~h}$ DM flows for total recovery of $\mathrm{Cr}_{2} \mathrm{O}_{3}$ (MacRae \& Armstrong, 1969). The concentrations of $\alpha$-glucoside in the feed, duodenal, ileal and faecal DM were then multiplied by the relevant corrected DM flow to determine the flows of $\alpha$-glucoside. Observed differences between diets were analysed by a Student's $t$ test. 
Net absorption studies. Mean values for each sheep were used in all calculations. Glucose turnover rate (GTR) was calculated from the equation:

$$
\operatorname{GTR}(\mathrm{mmol} / \mathrm{h})=\frac{\left[6-{ }^{3} \mathrm{H}\right] \mathrm{glucose} \text { infusion rate }(\mathrm{nCi} / \mathrm{h})}{\text { equilibrium specific activity }(\mathrm{nCi} / \mathrm{mmol})}
$$

The rate of blood flow at the sampling catheter tip in the mesenteric vein and values for the net absorption of D-lactate, of L-lactate and of glucose were calculated as described by Katz \& Bergman (1969) and Bergman et al. (1970). Arterial glucose utilization by the small intestinal viscera was calculated by the arterial extraction ratio method of Bergman et al. (1970), except that $\left[6{ }^{-3} \mathrm{H}\right]$ glucose, and not $\left[\mathrm{U}-{ }^{14} \mathrm{C}\right] \mathrm{glucose}$, was used. A model of glucose and lactate metabolism across the mesenteric-drained viscera was constructed (Fig. 1, p. 455). It was assumed that the mesenteric venous specific activity was equal to the intracellular specific activity, and that all glucose was metabolized via lactate, or through pathways in equilibrium with that of lactate. Observed rates of 'lactate' production and utilization, therefore, may also include the metabolism of other $\mathrm{C}_{3}$ compounds. These assumptions are necessary in order to solve the model. Steady-state conditions are also required to prevent changes in the size of the intracellular glucose and lactate pools. The following relations were used to solve the model:

$$
\begin{gathered}
\text { R1.GSRAA }=(\mathrm{R} 2+\mathrm{R} 5+\mathrm{R} 4) . \mathrm{GSRAV}, \\
(\mathrm{R} 6 . \mathrm{LSRAA})+(\mathrm{R} 5 . \mathrm{GSRAV})=(\mathrm{R} 7+\mathrm{R} 9) . \mathrm{LSRAV}, \\
\mathrm{R} 3=\mathrm{R} 2+\mathrm{R} 4+\mathrm{R} 5-\mathrm{R} 1, \\
\mathrm{R} 8=(\mathrm{R} 7+\mathrm{R} 9)-(\mathrm{R} 5+\mathrm{R} 6),
\end{gathered}
$$

where R1-R9 are the metabolite fluxes $(\mathrm{mg} \mathrm{C} / \mathrm{h})$ as shown in Fig. 1, GSRAA and GSRAV are the arterial and venous glucose specific activities $(\mathrm{nCi} / \mathrm{mg} \mathrm{C})$ respectively and LSRAA and LSRAV are the arterial and venous lactate specific activities ( $\mathrm{nCi} / \mathrm{mg} \mathrm{C}$ ) respectively. The proportion of lactate produced in the whole-body derived from glucose was calculated by the specific activity ratio, arterial lactate: glucose specific activities. The total addition of lactate across the gut is equal to $\mathrm{R} 5+\mathrm{R} 8$ and thus the proportion of lactate produced in the gut derived from glucose is:

$$
\frac{\mathrm{R} 5}{\mathrm{R} 5+\mathrm{R} 8} \text {. }
$$

Statistical analysis of the between-diet differences was by two-way analysis of variance with diet as a fixed effect and sheep as a random effect. Arterial-mesenteric venous concentration differences within each diet were analysed by a paired $t$ test.

\section{RESULTS}

Net disappearance studies. Values relating to $\alpha$-glucoside entering and leaving the small intestine are shown in Table 1. When the maize-based diet was fed, although the major portion of the digestion of $\alpha$-glucoside occurred in the rumen, a considerable amount of the polymer passed into the small intestine. The apparent digestibility of this $\alpha$-glucoside in the small intestine was almost complete. With the dried-grass diet, only a small amount of $\alpha$-glucoside, significantly less $(P<0.01)$ than that observed for the maize-based diet, passed into the small intestine. The daily flow of $\alpha$-glucoside at the terminal ileum did not differ significantly between diets.

Net absorption studies. Blood glucose concentrations during the infusion periods were 
Table 1. The apparent digestibility of $\alpha$-glucoside in sheep fed on dried-grass or maize-based diets

(Values represent the means with their standard errors for four sheep. One diet only was given to each sheep)

\begin{tabular}{|c|c|c|c|c|c|}
\hline \multirow[t]{2}{*}{ Diet... } & \multicolumn{2}{|c|}{ Dried-grass } & \multicolumn{2}{|c|}{ Maize-based } & \multirow{2}{*}{$\begin{array}{c}\text { Statistical } \\
\text { significance of } \\
\text { between-diet } \\
\text { difference }\end{array}$} \\
\hline & Mean & $\mathrm{SE}$ & Mean & $\mathrm{SE}$ & \\
\hline Live body-wt (kg) & $54 \cdot 9$ & $2 \cdot 6$ & $55 \cdot 1$ & $0 \cdot 9$ & NS \\
\hline \multicolumn{6}{|l|}{ Amount of $\alpha$-glucoside $(\mathrm{g} / 24 \mathrm{~h})$} \\
\hline In feed & 47 & - & 503 & - & - \\
\hline Entering small intestine & $13 \cdot 9$ & $1 \cdot 5$ & $95 \cdot 4$ & $16 \cdot 2$ & *** \\
\hline Leaving small intestine & $5 \cdot 5$ & $0 \cdot 6$ & $4 \cdot 0$ & 1.9 & NS \\
\hline In faeces & $2 \cdot 7$ & 0.4 & nd & - & $* * *$ \\
\hline $\begin{array}{l}\text { Coefficient of apparent digestibility } \\
\text { of } \alpha \text {-glucoside }\end{array}$ & 0.94 & 0.01 & 1.00 & 0.00 & *** \\
\hline \multicolumn{6}{|l|}{$\begin{array}{l}\text { Proportion of apparently digested } \\
\alpha \text {-glucoside disappearing: }\end{array}$} \\
\hline In rumen & 0.75 & 0.04 & $0 \cdot 81$ & 0.03 & NS \\
\hline In small intestine & $0 \cdot 19$ & 0.03 & $0 \cdot 18$ & 0.03 & NS \\
\hline In caecum and colon & $0 \cdot 06$ & 0.01 & 0.01 & 0.01 & * \\
\hline
\end{tabular}

nd, Not detected, NS, not significant.

${ }^{*} P<0.05,{ }^{* *} P<0.01,{ }^{* * *} P<0.001$; Student's $t$ test.

fairly constant, the mean coefficient of variation within an infusion being 3.1 (SE 0.6$) \%$, indicating satisfactory steady-state conditions. The mean concentrations of D-lactate, L-lactate and glucose in mesenteric venous and arterial blood and the net absorption of these compounds across the small intestine are shown in Table 2. Concentrations of L-lactate in the blood were greater than those of D-lactate for both dietary regimens. L-lactate and D-lactate concentrations in the mesenteric and arterial blood tended to be greater when the maize-based diet was fed, although the differences were not significant. Positive net D-lactate and L-lactate absorptions were not always observed in all animals on either diet, indicating some net utilization by the intestinal viscera.

Arterial blood glucose concentrations were similar in both dietary periods. Mesenteric venous blood glucose concentrations were significantly greater $(P<0.001)$ than those in the arterial blood when the maize-based diet was given. When the dried-grass diet was given, mesenteric venous-arterial differences in blood glucose concentrations were negative (indicating net utilization), although these differences were not significant. The large, positive net absorption of glucose observed when the maize-based diet was given was significantly different from that observed for the dried-grass diet $(P<0.001)$.

The rate of glucose utilization by the small intestinal viscera, derived from the model of glucose and lactate interrelations (Fig. 1), and the contribution of absorbed glucose to whole-body GTR are shown in Table 3 . The GTR was significantly greater $(P<0.05)$ when the sheep were fed on the maize-based diet, compared with the dried-grass diet. This was primarily due to the large total absorption of glucose when the maize-based diet was given, which was significantly greater $(P<0.001)$ than that observed for the dried-grass diet. The contribution of absorbed glucose to the GTR was significantly greater $(P<0.001)$ when the maize-based diet was given. However, endogenous glucose production was significantly lower $(P<0.01)$ for the maize-based diet. For the dried-grass diet, the amount of glucose utilized by the intestinal tissues was slightly greater than the amount of glucose absorbed, 
Table 2. Blood concentrations and net absorption across the mesenteric-drained viscera of $D$-lactate, L-lactate and glucose in sheep fed on dried-grass or maize-based diets

(Values represent the means with their standard errors for five sheep)

\begin{tabular}{|c|c|c|c|c|c|}
\hline \multirow[t]{2}{*}{ Diet... } & \multicolumn{2}{|c|}{ Dried-grass } & \multicolumn{2}{|c|}{ Maize-based } & \multirow{2}{*}{$\begin{array}{l}\text { Statistical } \\
\text { significance of } \\
\text { between-diet } \\
\text { difference }\end{array}$} \\
\hline & Mean & SE & Mean & SE & \\
\hline Mesenteric blood flow $(\mathrm{l} / \mathrm{h})$ & $94 \cdot 8$ & $4 \cdot 7$ & $105 \cdot 0$ & $9 \cdot 6$ & NS \\
\hline \multicolumn{6}{|c|}{ Blood D-lactate concentration (mM): } \\
\hline Arterial & $0 \cdot 32$ & $0 \cdot 12$ & 0.36 & $0 \cdot 13$ & NS \\
\hline Mesenteric & $0 \cdot 31$ & $0 \cdot 12$ & $0 \cdot 34$ & $0 \cdot 12$ & NS \\
\hline \multicolumn{6}{|c|}{ Blood L-lactate concentration (mM): } \\
\hline Arterial & 0.77 & $0 \cdot 30$ & $0 \cdot 80$ & $0 \cdot 21$ & NS \\
\hline Mesenteric & 0.77 & $0 \cdot 29$ & 0.78 & $0 \cdot 20$ & NS \\
\hline \multicolumn{6}{|c|}{ Blood glucose concentration (mM): } \\
\hline Arterial & $3 \cdot 18$ & $0 \cdot 14$ & $3 \cdot 17$ & $0 \cdot 10$ & NS \\
\hline Mesenteric & $3 \cdot 15$ & $0 \cdot 14$ & $3 \cdot 36$ & $0 \cdot 11$ & NS \\
\hline \multicolumn{6}{|c|}{ Net intestinal absorption $(\mathrm{mmol} / \mathrm{h})$ : } \\
\hline D-Lactate & $-0 \cdot 71$ & $1 \cdot 07$ & $-2 \cdot 14$ & $1 \cdot 79$ & NS \\
\hline L-Lactate & 0.07 & 1.07 & $-2 \cdot 53$ & $1 \cdot 33$ & NS \\
\hline Glucose & $-2 \cdot 03$ & $1 \cdot 20$ & $19 \cdot 28$ & 0.75 & $* * *$ \\
\hline
\end{tabular}

NS, not significant.

**** $P<0.001$.

Table 3. Glucose turnover and glucose and L-lactate metabolism by the mesenteric-drained viscera

(Values represent means with their standard errors for five sheep)

\begin{tabular}{|c|c|c|c|c|c|}
\hline \multirow[t]{2}{*}{ Diet... } & \multicolumn{2}{|c|}{ Dried-grass } & \multicolumn{2}{|c|}{ Maize-based } & \multirow{2}{*}{$\begin{array}{c}\text { Statistical } \\
\text { significance of } \\
\text { between-diet } \\
\text { difference }\end{array}$} \\
\hline & Mean & SE & Mean & $\mathrm{SE}$ & \\
\hline $\begin{array}{l}\text { Whole-body glucose turnover rate } \\
\text { (GTR; mmol/h) }\end{array}$ & $28 \cdot 42$ & $1 \cdot 33$ & 38.92 & $3 \cdot 19$ & * \\
\hline $\begin{array}{l}\text { Arterial glucose utilized by } \\
\text { mesenteric-drained viscera }(\mathrm{mmol} / \mathrm{h})\end{array}$ & $3 \cdot 52$ & $0 \cdot 38$ & 3.75 & $1 \cdot 14$ & NS \\
\hline $\begin{array}{l}\text { Total glucose utilized by } \\
\text { mesenteric-drained viscera } \\
(\mathrm{R} 5 ; \mathrm{mmol} / \mathrm{h})\end{array}$ & 3.56 & 0.39 & $4 \cdot 03$ & 1.23 & NS \\
\hline Total glucose absorbed $(\mathrm{R} 3 ; \mathrm{mmol} / \mathrm{h})$ & 1.52 & $1 \cdot 35$ & $23 \cdot 33$ & $1 \cdot 86$ & $* * *$ \\
\hline Endogenously produced glucose $\dagger(\mathrm{mmol} / \mathrm{h})$ & $26 \cdot 89$ & $2 \cdot 20$ & $15 \cdot 59$ & $3 \cdot 18$ & ** \\
\hline $\begin{array}{l}\text { Proportionate contribution of } \\
\text { absorbed glucose to the GTR }\end{array}$ & 0.08 & 0.04 & $0 \cdot 61$ & 0.05 & $* * *$ \\
\hline $\begin{array}{l}\text { Proportion of L-lactate produced by } \\
\text { mesenteric-drained viscera derived } \\
\text { from glucose }\end{array}$ & 0.41 & 0.08 & 0.44 & 0.06 & NS \\
\hline $\begin{array}{l}\text { Proportion of L-lactate produced in } \\
\text { whole body derived from glucose }\end{array}$ & 0.28 & 0.02 & 0.39 & 0.07 & NS \\
\hline
\end{tabular}

NS, not significant.

* $P<0.05, * * P<0.01$, *** $P<0.00$ 1.

+ Calculated from the difference between the whole-body GTR and the total glucose absorbed. 
Intestinal tissue

(a) 108 (96)

(b) 1680 (132)
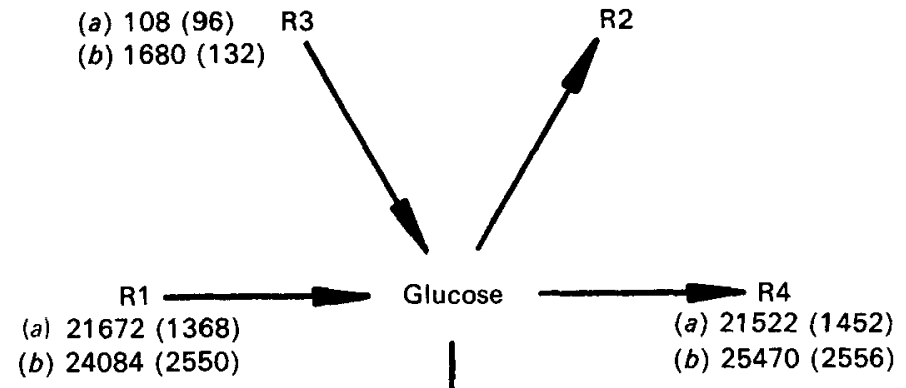

R5 (a) $258(30)$

(b) $288(90)$

Arterial

blood

input

(2550)

$\mathrm{R} 6$

(a) 2478 (876)

(b) 3090 (948)

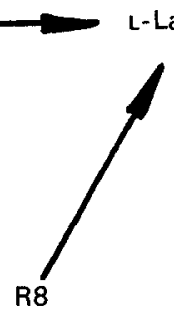

(a) $462(150)$

(b) 336 (48)

Intestinal tissue

(a) $714(156)$

(b) $672(120)$

(a) $2478(852)$

(b) 3036 (948)
Venous

blood output

Fig. 1. Model of glucose and $\mathbf{L}$-lactate interrelations across the mesenteric-drained viscera. $\mathbf{R} 1$ and $\mathbf{R} 4$ are the rates of blood glucose supplying and leaving the intestinal tissues respectively; $R 6$ and $R 9$, the rates of blood L-lactate supplying and leaving the intestinal tissues respectively; $R 2$, the rate of glucose metabolized in the intestinal tissues by non-glycolytic pathways, assumed to be zero; $R 3$, the rate of glucose absorption from the intestinal lumen; R5, the rate of metabolism of glucose to L-lactate (or compounds in equilibrium with L-lactate) in the intestinal tissues; $R 7$, the rate of metabolism of the $L$-lactate (or compounds in equilibrium with L-lactate) in the intestinal tissues; R8, the rate of L-lactate absorption from the intestinal lumen. Values $(\mathrm{mg}$ carbon/h) represent means with their standard errors in parentheses for five sheep fed on either (a) dried-grass or (b) maize-based diets.

resulting in a negative net glucose absorption. There was no significant between-diet difference in glucose utilization by the mesenteric-drained viscera; it should be noted, however, that the use of an arterial extraction ratio (Bergman et al. 1970) slightly underestimates total utilization due to metabolism of absorbed glucose.

For both diets, a large amount of lactate (and compounds in equilibrium with lactate) was produced by the post-rumen tract, derived from both endogenous production by the intestinal tissues and absorption from the small intestinal lumen. However, for both diets, the rate of metabolism of lactate was virtually equal to the rate of production. Diet did not influence the proportion of lactate produced by the intestinal tissues that was derived from the metabolism of glucose. Compared with the dried-grass diet, the proportion of 
lactate derived from glucose in the whole body tended to be greater when the maize-based diet was given. For both diets the proportion of lactate derived from glucose metabolism in the mesenteric-drained viscera was greater than that derived from glucose metabolism in the whole body, although the differences were not significant.

\section{DISCUSSION}

Evidence relating to the absorption of glucose from the ruminant small intestine when maize-based diets are given is conflicting. The concentrate diet fed to sheep by Bergman et al. (1970) contained some maize, but no absorption of glucose into the portal venous blood was detected. Several studies with cattle given large quantities of ground-maize have shown a negative net absorption of glucose into the portal blood (Huntington et al. 1981; Huntington, 1982, 1983). On the other hand, Huntington et al. (1980) reported positive net and total absorptions of glucose into the portal venous blood of sheep fed ad lib. on a maize-based diet. When the same diet was given to cattle at three different levels of intake, a net absorption of glucose into the portal venous blood was observed, but only at the two highest levels of intake (Huntington \& Prior, 1983). Further qualitative evidence of glucose absorption from the digestive tract has been reported in maize-fed sheep (Thivend, 1974) and cattle (Fries \& Conner, 1960; Symonds \& Baird, 1975). In the present study, a large net and total absorption of glucose into the mesenteric venous blood was observed when the sheep were fed on a ground, maize-based diet. The net amount of glucose absorbed was greater than that determined in sheep with arterial and portal venous catheters, fed on a diet containing $780 \mathrm{~g}$ ground maize $/ \mathrm{kg}(8.09 \mathrm{mmol} / \mathrm{h}$; Huntington et al. 1980).

Apparently, only a small proportion of the glucose absorbed from the small intestine is metabolized during transport into the blood, with the major portion of the glucose utilized by the mesenteric-drained viscera being derived from the arterial glucose supply. Arterial blood glucose utilization by the mesenteric-drained viscera in the sheep when fed on the dried-grass diet in the present study was greater than that by the portal-drained viscera of sheep fed on lucerne (Medicago sativum) hay ad lib. (Huntington et al. 1980), although when expressed on a body-weight basis, the two rates are similar (13 and $12 \mathrm{mg}$ glucose/h per $\mathrm{kg}$ live weight respectively). Similarly, the rate of arterial blood glucose utilization by the portal-drained viscera of sheep fed on $800 \mathrm{~g}$ lucerne hay $/ \mathrm{d}$ was $11 \mathrm{mg} / \mathrm{h} \mathrm{per} \mathrm{kg}$ live weight (Bergman et al. 1970). The estimates of total glucose utilization by the mesenteric-drained viscera may be affected by the assumptions required to solve the model of glucose and lactate metabolism, particularly the assumption that all glucose is metabolized via compounds in equilibrium with lactate. The rate of total glucose utilization by the mesenteric-drained viscera on either diet is less than rates relating to the portal-drained viscera of pregnant and lactating sheep, calculated by Van der Walt et al. (1983) using a more complete model of glucose and lactate metabolism in the gut. However, due to differences in physiological status, diet, method of feeding and the fact that metabolism by the tissues of the reticulo-rumen was not included in the values obtained in the present study, a comparison of the results obtained from the two models cannot really be made. In the present study, glucose utilization by the mesenteric-drained viscera was not affected by diet. However, Bergman et al. (1970) and Huntington et al. (1980) observed trends towards an increase in visceral glucose utilization when a concentrate, instead of a roughage diet was given. When expressed on a body-weight basis, the rate of glucose utilization by the portaldrained viscera in lambs fed on a maize-based concentrate (Huntington et al. 1980) was more than twice that observed in the present study $(31$ and $14 \mathrm{mg} / \mathrm{h}$ per $\mathrm{kg}$ live weight respectively). Although the two experiments are not strictly comparable, with differences 
in diet composition, level of intake and methodology, the difference between these two values may represent glucose utilization by the tissues of the reticulo-rumen.

The total amount of glucose absorbed from the small intestine when the sheep were fed on the dried-grass diet represented only a small proportion of the whole-body GTR. However, when the maize-based diet was given, the contribution of absorbed glucose to the GTR was considerable $(0.61)$ and is much greater than that observed previously in sheep fed on a maize-based diet $(0 \cdot 25$; Huntington et al. 1980). Although the rate of endogenous glucose production was much lower when the maize-based diet was given, the difference between the values for the two diets was not as great as the difference in the rate of glucose absorption. Thus, the sparing of endogenous precursors by exogenous glucose was not on a $1: 1$ basis, causing a greater GTR when the maize-based diet compared with the dried-grass diet was given.

Assuming that the sampling period in the absorption experiments was representative of a $24 \mathrm{~h}$ period, the total amount of glucose absorbed into the mesenteric venous blood was equivalent to 7 and $101 \mathrm{~g}$ glucose/d for the dried-grass and maize-based diets respectively. The measurement of total glucose absorption includes glucose metabolized by the small intestinal viscera, but does not take into account the fermentation of $\alpha$-glucoside by a microbial flora within the lumen of the small intestine. These values are in broad agreement with the values for the apparent net disappearance of $\alpha$-glucoside from the small intestine, derived from amounts entering and leaving the small intestine $(9$ and $91 \mathrm{~g} / \mathrm{d}$ for the dried-grass and maize-based diets respectively). Clearly, caution must be exercised in comparing the results from the two experiments reported in the present paper, since different animals were used. Nevertheless, when consideration is given to the very different techniques used in each experiment, the agreement in the results obtained is good. This suggests that a major proportion of the considerable amounts of starch which apparently disappeared from the small intestine of the sheep on the maize-based diet was absorbed as glucose, although a small portion of this may have been metabolized during transport across the intestinal wall.

The authors would like to thank Dr D. S. Parker for performing the surgery and Mr D. M. Smith and Miss L. Hedgcock for post-operative care of the animals. This work was supported by a Research Grant from the Agricultural and Food Research Council.

\section{REFERENCES}

Armstrong, D. G. \& Smithard, R. R. (1979). Proceedings of the Nutrition Society 38, 283-294.

Beever, D. E., Coelho Da Silva, J. F. \& Armstrong, D. G. (1970). Proceedings of the Nutrition Society 29, 43A.

Bergman, E. N., Katz, M. L. \& Kaufman, C. F. (1970). American Journal of Physiology 219, 785-793.

Clary, J. J., Mitchell, G. E. \& Little, C. O. (1967). Journal of Animal Science 26, 917.

Eilers, R. J. (1967), American Journal of Clinical Pathology 47, 212-214.

Fries, G. F. \& Conner, G. H. (1960). Journal of Dairy Science 43, 1851-1852.

Gawehn, K. \& Bergmeyer, H. U. (1974). In Methods in Enzymatic Analysis, pp. 1492-1495 [H. U. Bergmeyer, editor]. New York: Academic Press.

Hogue, D. E., Elliot, J. M., Walker, E. F. \& Vidal, H. (1968). Proceedings of the Cornell Nutrition Conference 34, 57-60.

Huntington, G. B. (1982), Journal of Dairy Science 65, 1155-1162.

Huntington, G. B. (1983). Journal of Nutrition 113, 1157-1164.

Huntington, G. B. \& Prior, R. L. (1983). Journal of Nutrition 113, 2280-2288.

Huntington, G. B., Prior, R. L. \& Britton, R. A. (1980). Journal of Nutrition 110, 1904-1913.

Huntington, G. B., Prior, R. L. \& Britton, R. A. (1981). Journal of Nutrition 111, 1164-1172.

Janes, A. N., Parker, D. S., Weekes, T. E. C. \& Armstrong, D. G. (1984). Journal of Agricultural Science, Cambridge 103, 549-553. 
Janes, A. N., Weekes, T. E. C. \& Armstrong, D. G. (1985). Journal of Agricultural Science, Cambridge 104, 435-443.

Karr, M. R., Little, C. O. \& Mitchell, G. E. (1966). Journal of Animal Science 25, 652-654.

Katz, J., Okajima, F., Chenoweth, M. \& Dunn, A. (1981). Biochemical Journal 194, 513-524.

Katz, M. L. \& Bergman, E. N. (1969). American Journal of Physiology 216, 946-952.

MacRae, J. C. \& Armstrong, D. G. (1966). Proceedings of the Nutrition Society 25, xxxiii.

MacRae, J. C. \& Armstrong, D. G. (1969). British Journal of Nutrition 23, 15-23.

Mayes, R. W. \& Ørskov, E. R. (1974). British Journal of Nutrition 32, 143-153.

Ørskov, E. R., Fraser, C. \& Kay, R. N. B. (1969). British Journal of Nutrition 23, 217-226,

Russell, J. R., Young, A. W. \& Jorgensen, N. A. (1981). Journal of Animal Science 52, 1177-1182.

Symonds, H. W. \& Baird, G. D. (1975). British Veterinary Journal 131, 17-22.

Thivend, P. (1974). Proceedings of the Nutrition Society 33, 7A.

Tucker, R. E., Little, C. O., Mitchell, G. E., Hayes, B. W. \& Karr, M. R. (1966). Journal of Animal Science 25, 911.

Tucker, R. E., Mitchell, G. E. \& Little, C. O. (1968). Journal of Animal Science 27, 824-826.

Van der Walt, J. G., Baird, G. D. \& Bergman, E. N. (1983). British Journal of Nutrition 50, $267-280$.

Williams, C. H., David, D. J. \& Ismaa, O. I. (1962). Journal of Agricultural Science, Cambridge 59, 381 -385. 